\title{
Synthesis, characterization and evaluation of biological activities of manganese-doped zinc oxide nanoparticles
}

\author{
Shakeel Ahmad Khan ${ }^{1 *}$, Sammia Shahid ${ }^{1}$, Waqas Bashir ${ }^{1}$, Sadia Kanwal ${ }^{2}$ and \\ Ahsan Iqbal ${ }^{3}$ \\ ${ }^{1}$ Department of Chemistry, University of Management and Technology, Lahore-54000, ${ }^{2}$ Department of Biochemistry, University \\ of Agriculture, ${ }^{3}$ Government College University Faisalabad-38000, Pakistan
}

${ }^{*}$ For correspondence: Email: Shakilahmad56@gmail.com; Tel: +92-3441865064

\begin{abstract}
Purpose: To synthesize, characterize and investigate the antimicrobial properties of pure and manganese-doped zinc oxide nanoparticles.

Method: Un-doped and manganese-doped zinc oxide (Mn-doped $\mathrm{ZnO}$ ) nanoparticles were prepared using co-precipitation method. The synthesized $\mathrm{Mn}$-doped $\mathrm{ZnO}$ nanoparticles were characterized using energy-dispersive $x$-ray spectroscopy (EDX), scanning electron microscopy (SEM), and $x$-ray diffraction (XRD) spectroscopic techniques. Their band gap energies were measured with ultraviolet-visible (UVVis) spectroscopy, while their antioxidant properties were evaluated by ferric reducing antioxidant power (FRAP), DPPH radical-scavenging, ferric thiocyanate (FTC) and total phenolic content (TPC) assays. The antimicrobial activities of the nanoparticles against different bacterial strains were determined using agar diffusion method.

Result: Results from XRD, SEM, EDX and UV-Vis analyses demonstrated successful synthesis of undoped and Mn-doped $\mathrm{ZnO}$ nanoparticles as seen in their hexagonal, wurtzite structures. The un-doped and $\mathrm{Mn}$-doped $\mathrm{ZnO}$ nanoparticles had average grain sizes of $16.72 \mathrm{~nm}$ and $17.5 \mathrm{~nm}$, and band gap energies of $3.585 \mathrm{eV}$ and $2.737 \mathrm{eV}$, respectively. Significant antibacterial activity was manifested by Mndoped $\mathrm{ZnO}$ against E. coli, S. aureus, Klebsiella and B. subtilis, with zones of inhibition (ZOIs) of $13 \pm$ $0.09 \mathrm{~mm}, 14 \pm 0.01 \mathrm{~mm}, 18 \pm 0.07 \mathrm{~mm}$ and $20 \pm 0.10 \mathrm{~mm}$, respectively. The Mn-doped $\mathrm{ZnO}$ nanoparticles also exhibited effective and significant antioxidant potential relative to butylated hydroxytoluene (BHT) and un-doped $\mathrm{ZnO}$ nanoparticles.

Conclusion: Mn-doped ZnO nanoparticles demonstrate significant antimicrobial and antioxidant activities. Thus, the preparation is a good candidate for further development into therapeutic formulations.
\end{abstract}

Keywords: Mn-doped ZnO, Nanoparticles, Properties, Antioxidant, Antibacterial

Tropical Journal of Pharmaceutical Research is indexed by Science Citation Index (SciSearch), Scopus, International Pharmaceutical Abstract, Chemical Abstracts, Embase, Index Copernicus, EBSCO, African Index Medicus, JournalSeek, Journal Citation Reports/Science Edition, Directory of Open Access Journals (DOAJ), African Journal Online, Bioline International, Open-J-Gate and Pharmacy Abstracts

\section{INTRODUCTION}

Zinc oxide $(\mathrm{ZnO})$ nanoparticles have received much attention in recent years due to their diverse applications [1]. Nowadays, prototype $\mathrm{ZnO}$ nanoparticles are used as delivery systems for vaccines and anti-cancer drugs [2]; as antimicrobial agents, additives in industrial products and photo-catalysts for disintegrating organic materials [3]. However, ZnO nanostructures are still being widely studied with a view to enhancing their potential applications in the field of biomedicine [2].

It has been reported that the functionality and efficiency of $\mathrm{ZnO}$ nanoparticles and 
nanostructures can be improved by increasing and modifying their surface areas through nanoscale addition of some dopants materials such as biomolecules and transition metals $(\mathrm{Mn}, \mathrm{Fe}, \mathrm{Cr}$, $\mathrm{Cu}$ [4]. This surface modification with biomolecules and transition metals confers new properties on $\mathrm{ZnO}$ nanoparticles so they can function as biosensors, antimicrobial, antioxidants, drug delivery systems and bioimaging materials $[1,4,5]$.

Different methods have been developed for the fabrication of un-doped $\mathrm{ZnO}$ and transition metaldoped $\mathrm{ZnO}$ nanoparticles [6]. Manganese $(\mathrm{Mn})$ is the metal of choice for doping of $\mathrm{ZnO}$ nanoparticles because of the ready availability of its $d$ electrons at $t_{2} g$ level, and also for the fact that these electrons can easily overlap with the valance bond of $\mathrm{ZnO}$ nanoparticles $[4,5]$.

It has been demonstrated that if $\mathrm{ZnO}$ nanoparticles are doped with $\mathrm{Mn}$, the products have enhanced antibacterial [2] and magnetic properties [3] which may be acceptable for biomedical and spintronic applications [4]. The enhancement of the antioxidant and antimicrobial properties is due to the fact that doping of $\mathrm{ZnO}$ nanoparticles with $\mathrm{Mn}$ increases the surface area and reduces particle size of $\mathrm{ZnO}$ nanoparticles [7], Thus, studies aimed at investigating the biological, optical, and magnetic properties of Mn-doped $\mathrm{ZnO}$ nanoparticles have attracted much interest [8].

The purpose of the present study was to synthesize and characterize un-doped $\mathrm{ZnO}$ and Mn-doped $\mathrm{ZnO}$ nanoparticles, and investigate their antibacterial and antioxidant properties.

\section{EXPERIMENTAL}

All chemicals and reagents used were procured from Sigma-Aldrich (United States of America) and Merck (Germany) and were of analytical grade. These reagents included butylated hydroxytoluene (BHT; 99.07\% pure); 2, 2diphenyl-1-picrylhydrazyl (DPPH, 90.0\% pure); Folin-Ciocalteu reagent $(2 \mathrm{~N})$, linoleic acid and catechin.

\section{Preparation of solutions}

Zinc acetate $\left.\left[\mathrm{Zn}\left(\mathrm{CH}_{3} \mathrm{COO}\right)_{2} .2 \mathrm{H}_{2} \mathrm{O} ; 0.05 \mathrm{M}\right)\right]$ was prepared by dissolving $5.525 \mathrm{~g}$ of $\mathrm{Zn}$-acetate in distilled water in a $500-\mathrm{mL}$ volumetric flask, with solution level brought up to the mark, and then stirring for $10 \mathrm{~min}$. Thereafter, $0.05 \mathrm{M}$ solution of magnesium acetate $\left[\mathrm{Mn}\left(\mathrm{CH}_{3} \mathrm{COO}\right)_{2} .4 \mathrm{H}_{2} \mathrm{O}\right]$ was prepared by dissolving $1.235 \mathrm{~g}$ of $\mathrm{Mn}$-acetate in $100 \mathrm{~mL}$ distilled water in a measuring flask, followed by vortexing. Ammonia solution (35\%) was also prepared in distilled water.

\section{Synthesis of un-doped $\mathrm{ZnO}$ nanoparticles}

Zinc acetate $(0.05 \mathrm{M}, 450 \mathrm{~mL})$ was put in a 1000 $\mathrm{mL}$ beaker and stirred for $30 \mathrm{~min}$ at room temperature $\left(30{ }^{\circ} \mathrm{C}\right)$ using magnetic stirrer at the rate of $2000 \mathrm{rpm}$. Diluted ammonia (35\%) was added slowly with constant stirring for $1 \mathrm{~h}$, to a $\mathrm{pH}$ of about 10. After attaining the desired $\mathrm{pH}$ 10 , the reaction mixture was heated at $60^{\circ} \mathrm{C}$ with continuous stirring for $30 \mathrm{~min}$ using magnetic stirrer at the rate of $2000 \mathrm{rpm}$. Then reaction mixture was placed at room temperature (28-30 $\left.{ }^{\circ} \mathrm{C}\right)$ for $48 \mathrm{~h}$ for precipitation to occur. This resulted in the formation of white colored precipitates in the reaction mixture. To separate the precipitates, the reaction mixture was filtered and washed thrice with distilled water, and then further washed thrice with $30 \mathrm{~mL}$ of ethanol to remove impurities. Thereafter, the precipitates were filtered and oven-dried at $110{ }^{\circ} \mathrm{C}$ for $1 \mathrm{~h}$. The dried precipitates were milled using a pestle and mortar, and then the powder was heated in oven for $20 \mathrm{~min}$ at the same temperature (110 ${ }^{\circ} \mathrm{C}$ ) to remove any absorbed moisture. Then, calcination of the white powder was done at 200 ${ }^{\circ} \mathrm{C}$ for $3 \mathrm{~h}$ in a muffle furnace. This yielded white and fine un-doped $\mathrm{ZnO}$ nanoparticles which were kept in air tight container at room temperature $\left(25-30^{\circ} \mathrm{C}\right)$.

\section{Synthesis of Mn-doped ZnO nanoparticles}

The zinc acetate and manganese acetate solutions were employed, and ammonia (35\%) was used to adjust the $\mathrm{pH}$ to 10 . To $450 \mathrm{~mL}$ of $0.05 \mathrm{M} \mathrm{Zn}$ acetate in a $1000-\mathrm{mL}$ beaker was slowly and continuously added, with stirring, 50 $\mathrm{mL}$ of $0.05 \mathrm{M} \mathrm{Mn}$ acetate. The reaction mixture was stirred for 30 min using magnetic stirrer at the rate of $2000 \mathrm{rpm}$. Diluted ammonia was then added from the burette to the reaction mixture, at a flow rate of $2 \mathrm{~mL} / \mathrm{min}$ to attain $\mathrm{pH} \sim 10$. The reaction mixture was constantly stirred during the $\mathrm{pH}$ adjustment, at the rate $1000 \mathrm{rpm}$ in a magnetic stirrer. After the $\mathrm{pH}$ adjustment, the solution was further stirred with the magnetic stirrer at the rate of $1500 \mathrm{rpm}$ for $1 \mathrm{~h}$. Then the reaction mixture was heated at $60{ }^{\circ} \mathrm{C}$ for $30 \mathrm{~min}$, and placed at room temperature $\left(28-30{ }^{\circ} \mathrm{C}\right)$ for $48 \mathrm{~h}$ for precipitation to take place. This resulted in the formation of brown-colored precipitates in the reaction mixture. To separate out the precipitates, the reaction mixture was filtered and washed thrice with distilled water, and then washed thrice with $30 \mathrm{~mL}$ of ethanol to eliminate impurities. The precipitates were thereafter ovendried at $110{ }^{\circ} \mathrm{C}$ for $1 \mathrm{~h}$, and milled in a pestle and 
mortar. The brown, powdered nanoparticles were heated in an oven for $20 \mathrm{~min}$ at $110^{\circ} \mathrm{C}$ to remove any traces of absorbed moisture. Then, calcination of the brown powder was done at 200 ${ }^{\circ} \mathrm{C}$ for $3 \mathrm{~h}$ in a muffle furnace. This yielded brown and fine $\mathrm{Mn}$-doped $\mathrm{ZnO}$ nanoparticles that were kept in an air-tight container at room temperature $\left(25-30{ }^{\circ} \mathrm{C}\right)$ prior to use [9].

\section{Characterization of un-doped and Mn-doped ZnO nanoparticles}

Energy dispersive X-ray technique was employed for the determination of the composition and morphology of the synthesized un-doped and $\mathrm{Mn}$-doped $\mathrm{ZnO}$ nanoparticles. In addition, characterization of the crystalline structure of the nanoparticles was done using the XRD i.e. PANalytical X'Pert diffractometer instrument with $\mathrm{Cu}-\mathrm{Ka}$ radiation (wavelength $0.154 \mathrm{~nm}$ ) operating at $40 \mathrm{kV}$ and $30 \mathrm{~mA}$. Measurements were scanned for diffraction angles $(2 \theta)$ ranging from 20 to $90^{\circ}$ with a step size of $0.02^{\circ}$ and a time per step of $1 \mathrm{~s}$. The absorption spectrum and band gap energies of the synthesized nanoparticles were determined by UV-visible spectrophotometer (Spectra Flash SF 550, Data color Inc., USA), while their morphological features were determined using SEM (Jeol, 5910LV).

\section{Evaluation of antioxidant activity \\ DPPH free radical scavenging assay}

The antioxidant properties of the un-doped and $\mathrm{Mn}$-doped $\mathrm{ZnO}$ nanoparticles were determined by 2, 2-diphenyl-1-picrylhydrazyl (DPPH) radical scavenging capacity according to the method of Khan et al [10]. Butylated hydroxytoluene (BHT) was used as standard for comparison.

\section{Total phenolic content (TPC) assay}

The total phenolic content of the Mnu-doped $\mathrm{ZnO}$ NAPs was determined colorimetrically as described by Khan et al [11].

\section{Ferric reducing antioxidant power (FRAP) assay}

Antioxidant potential of un-doped and Mn-doped $\mathrm{ZnO}$ nanoparticles was also assessed by evaluating the ferric reducing antioxidant power as described by ljaz et al [12].

\section{Ferric thiocyanate (FTC) assay}

Antioxidant potential in terms of the inhibitory effect of the un-doped and Mn-doped $\mathrm{ZnO}$ nanoparticles on linoleic acid peroxidation was evaluated by the thiocyanate method of ljaz et al. [12].

\section{Evaluation of antibacterial activity}

The antibacterial properties of the synthesized un-doped and $\mathrm{Mn}$-doped $\mathrm{ZnO}$ nanoparticles were evaluated by using the Agar well diffusion method of Khan et al [13, 14]. The bacterial strains used for the determination of bactericidal activities were Bacillus subtilis ( $B$. subtitles), Escherichia coli (E. coli), Klebsiella and Staphylococcus aureus (S. aureus). S. aureus, Klebsiella and Bacillus subtilis represented Gram-positive bacteria while E. coli represented Gram-negative bacteria. Distilled water was used as negative control for the bacterial strains while bacteriological cephradine was used as standard antibiotic for positive control. Solutions of undoped $\mathrm{ZnO}$ and $\mathrm{Mn}$-doped $\mathrm{ZnO}$ nanoparticles in distilled water were prepared through ultrasonication method. Two different concentrations of solutions ( 3 and $5 \mathrm{mg} / \mathrm{mL}$ ) for the synthesized un-doped $\mathrm{ZnO}$ and $\mathrm{Mn}$-doped $\mathrm{ZnO}$ nanoparticles were used for evaluating the antibacterial potential, and the results were compared with those obtained for the standard drug (cephradine). For the reference antibiotic, $1 \mathrm{mg}$ was used in the present study.

\section{Statistical analysis}

Statistical analysis was done by one-way or twoway ANOVA and the Tukey post-test using Graph Pad Prism v6.04 software (Graph Pad Software, Inc., La Jolla, CA, USA). Differences were considered statistically significant at $p<0.05$. Group sizes are indicated in the figure legends. All values are expressed as mean \pm SD.

\section{RESULTS}

\section{Characteristics of synthesized nanoparticles}

\section{$X$-ray diffraction}

The XRD patterns for un-doped and Mn-doped $\mathrm{ZnO}$ nanoparticles are shown in Figure 1 (a) and Figure (b) respectively. The XRD pattern of undoped $\mathrm{ZnO}$ nanoparticles was uniform and no impurities were observed in the spectrum as shown in Figure 1(a). Moreover, the XRD pattern showed intense and sharp peaks which confirmed the crystalline nature of the un-doped $\mathrm{ZnO}$ nanoparticles. The formation of phase indicates pure wurtzite structure of $\mathrm{ZnO}$ nanoparticles which was confirmed by XRD peaks $31.7,34.35$, and 36.15 . As the highest 
peak (36.15) is the major peak homologous to hexagonal wurtzite structure.

The XRD results indicate good crystalline nature of un-doped $\mathrm{ZnO}$ nanoparticles because of intense and narrow peaks. The average grain size of un-doped $\mathrm{ZnO}$ nanoparticles was 16.72 $\mathrm{nm}$. Moreover, small broadening at the bottom of peaks indicated that the crystalline size was small [7]. The XRD pattern for Mn-doped $\mathrm{ZnO}$ nanoparticles is shown in Figure 1 (b). The XRD patterns of $\mathrm{Mn}$-doped $\mathrm{ZnO}$ nanoparticles were similar to those of XRD pattern of un-doped $\mathrm{ZnO}$ nanoparticles. The XRD results demonstrated that the peaks were narrow and sharp which confirmed the crystalline nature of the synthesized Mn-doped ZnO nanoparticles.

The average grain size for $\mathrm{Mn}$-doped $\mathrm{ZnO}$ nanoparticles was $17.5 \mathrm{~nm}$. The average size was slightly greater than that of the un-doped $\mathrm{ZnO}$ nanoparticles, obviously due to incorporation of $\mathrm{Mn}$. Grain size depends on percentage of doping element. The formation of phase indicated pure wurtzite structure of $\mathrm{Mn}$ -

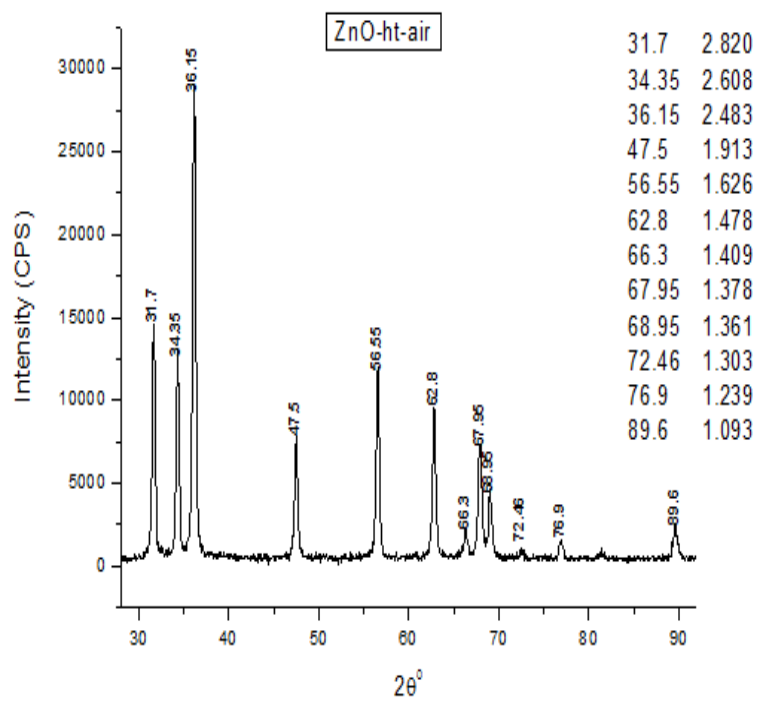

(a) doped $\mathrm{ZnO}$ nanoparticles which was confirmed by XRD peaks 25.65, 29.80, 31.30, 33.95, and 35.75. Figure 2(b) shows uniform XRD pattern, with no evidence of impurity in the Mn-doped $\mathrm{ZnO}$ nanoparticles [8]. The grain sizes of the undoped and $\mathrm{Mn}$-doped $\mathrm{ZnO}$ nanoparticles were calculated by Debye-Scherer's formula.

\section{Morphological characteristics}

Figures 2 (a) and (b) show the surface morphological and structural patterns of undoped ZnO nanoparticles using scanning electron microscope (SEM). SEM micrograph for un-doped $\mathrm{ZnO}$ nanoparticles indicated that the un-doped $\mathrm{ZnO}$ nanoparticles were fine particles with crystalline behavior. Moreover, SEM results also confirmed that the synthesized un-doped $\mathrm{ZnO}$ nanoparticles had particles size in nanometer in range.

Figure 2 (c) shows the micrograph for Mn-doped $\mathrm{ZnO}$ nanoparticles. SEM micrograph results demonstrated that the particle size of $\mathrm{Mn}$-doped $\mathrm{ZnO}$ nanoparticles was slightly larger than that of

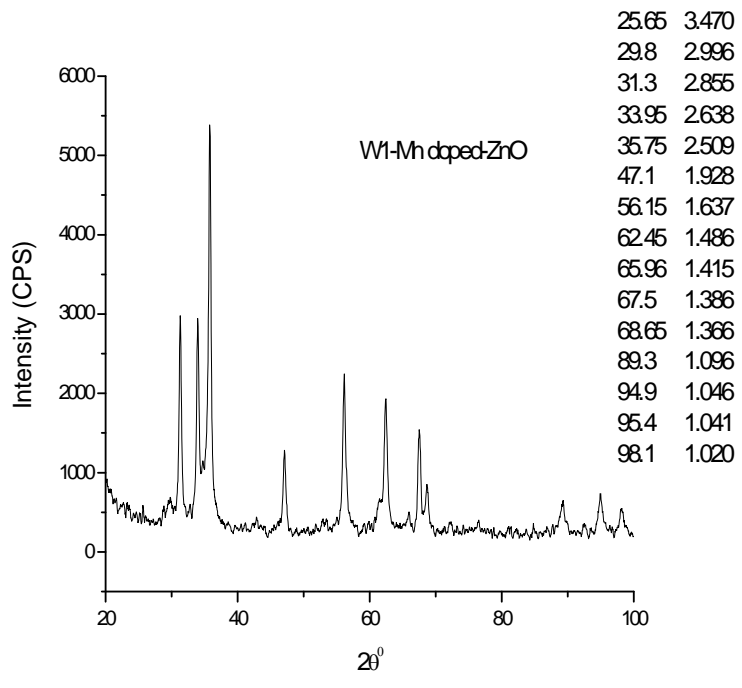

(b)

Figure 1: XRD pattern of un-doped $\mathrm{ZnO}$ (a) and Mn-doped $\mathrm{ZnO}$ nanoparticles (b)

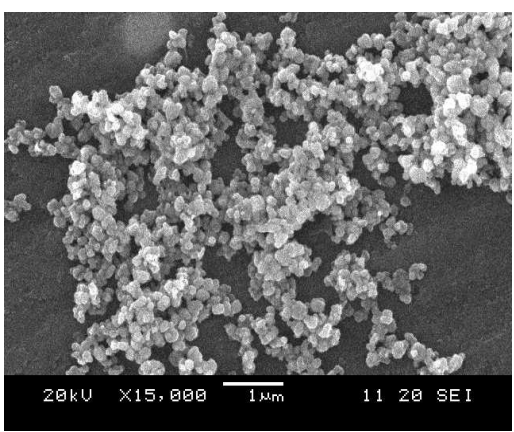

(a)

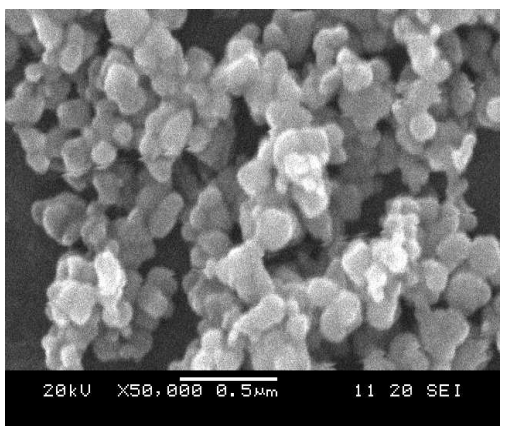

(b)

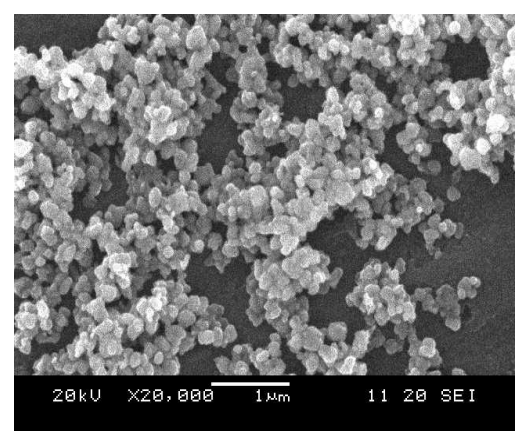

(c)

Figure 2: SEM micrographs of un-doped $\mathrm{ZnO}$ (a), (b) and Mn-doped ZnO nanoparticles (c) 
the un-doped $\mathrm{ZnO}$ nanoparticles. The enlargement of the particles size is due to the doping with $\mathrm{Mn}$. The same structural behavior of $\mathrm{Mn}$-doped $\mathrm{ZnO}$ nanoparticles was observed in XRD results in terms of particles size. Moreover, Figure 2 also indicates that the synthesized nanoparticles had good crystalline nature. A close relationship was observed between the results of XRD and SEM. The SEM images showed seed-like structures of un-doped $\mathrm{ZnO}$ and $\mathrm{Mn}$-doped $\mathrm{ZnO}$ nanoparticles which are consistent with earlier reports [15].

\section{EDX analysis}

EDX studies were carried out in order to examine the chemical formation and composition of the synthesized nanoparticles and also to confirm the presence of un-doped $\mathrm{ZnO}$ and $\mathrm{Mn}$-doped $\mathrm{ZnO}$ nanoparticles. Figures 3 (a) and (b) show the EDX spectra for un-doped $\mathrm{ZnO}$ and $\mathrm{Mn}$ doped $\mathrm{ZnO}$ nanoparticles, respectively. EDX spectra confirmed the presence of the constituents zinc $(\mathrm{Zn})$, oxygen $(\mathrm{O})$ in the nanoparticles. Hence, EDX spectra affirmed the presence of un-doped $\mathrm{ZnO}$ and $\mathrm{Mn}$-doped $\mathrm{ZnO}$ nanoparticles in the synthesized sample. It was clear from the EDX pattern that the nanoparticles were successfully synthesized. The consistent and sharp peaks with zinc oxide and manganese-zinc oxide demonstrated that both synthesized nanoparticles were crystalline in nature, and that peaks associated with impurities were absent in EDX spectra of both nanoparticles (un-doped $\mathrm{ZnO}$ and $\mathrm{Mn}$-doped $\mathrm{ZnO})$ [9]. Hence, nanoparticles were obtained in their pure forms.

\section{Band gap energy data}

Band gap is referred to as energy difference between the top valence bands and the bottom conduction band. It reflects the ability of electron
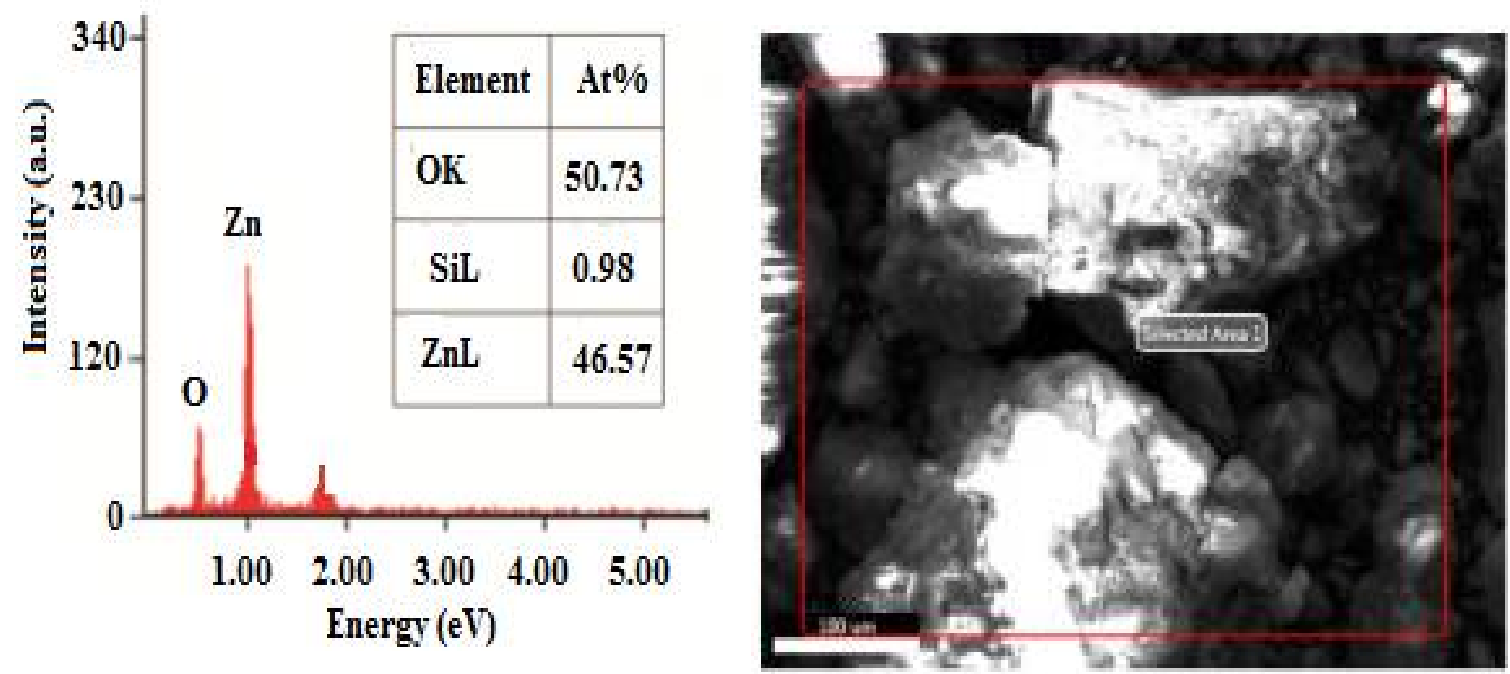

(a)
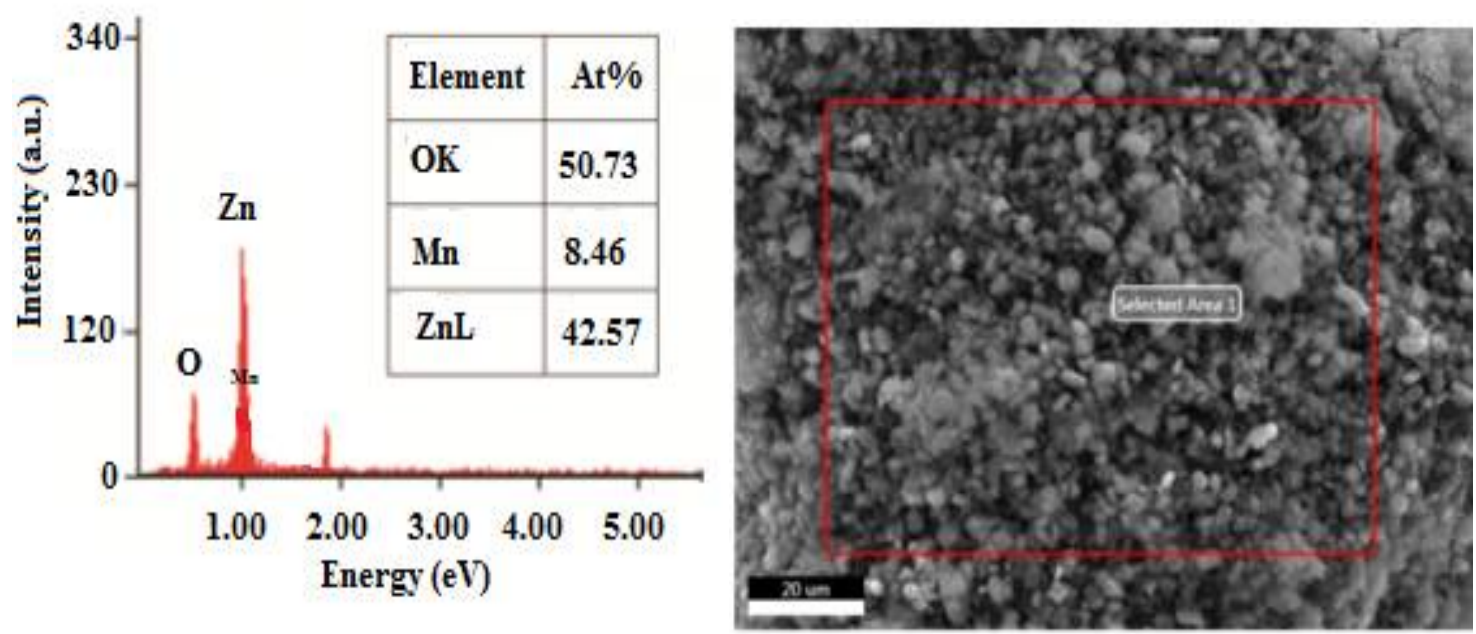

(b)

Figure 3: EDX spectrum of un-doped $\mathrm{ZnO}$ (a) and Mn-doped $\mathrm{ZnO}$ nanoparticles (b) 
to jump from one band to another. A specific minimum amount of energy is required for this transition. Measurement of band gap plays a vital role in semiconductors. The band gap energy of an insulator is large $(>4 \mathrm{eV})$, but is lower for a semiconductor $(<3 \mathrm{eV})$ [16]. The value of $E_{g}$ is achieved by the intersection between the photon energy axis and linear fit. The band gap energy of un-doped $\mathrm{ZnO}$ nanoparticles was $3.375 \mathrm{eV}$; while for $\mathrm{Mn}$-doped $\mathrm{ZnO}$ nanoparticles, band gap energy of $2.737 \mathrm{eV}$ was obtained [Figures 4 (a) and (b)]. Since $t_{2 g}$ level (i.e. the dxy, dxz, and dyz orbitals are collectively called the t2g orbitals) of $\mathrm{Mn}$ is very close to valence bonds (VB) of $\mathrm{ZnO}$, the d-electrons of $\mathrm{Mn}$ can easily overlap with the valence band of $\mathrm{ZnO}$ [17]. Being semiconductors, the band gap energy of $\mathrm{Mn}$ -

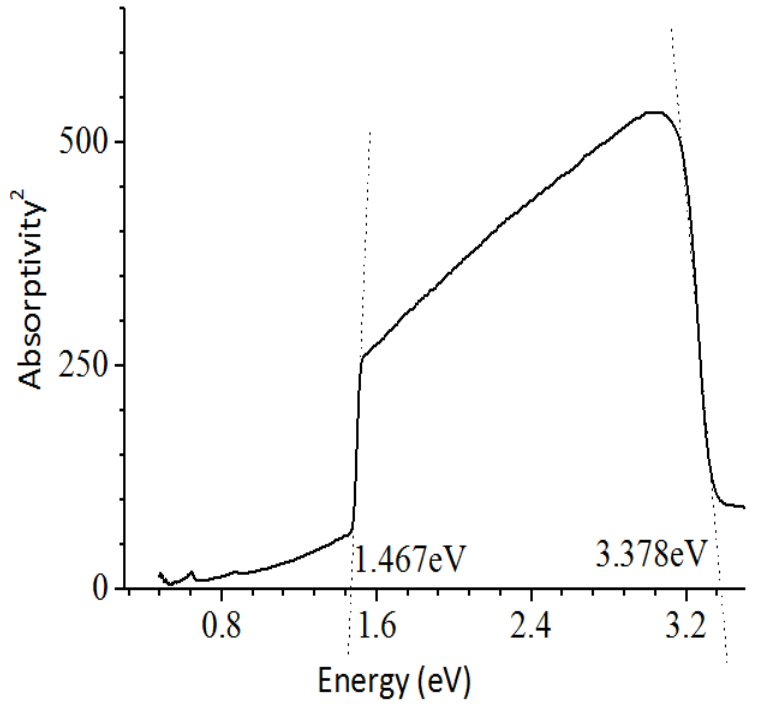

(a)

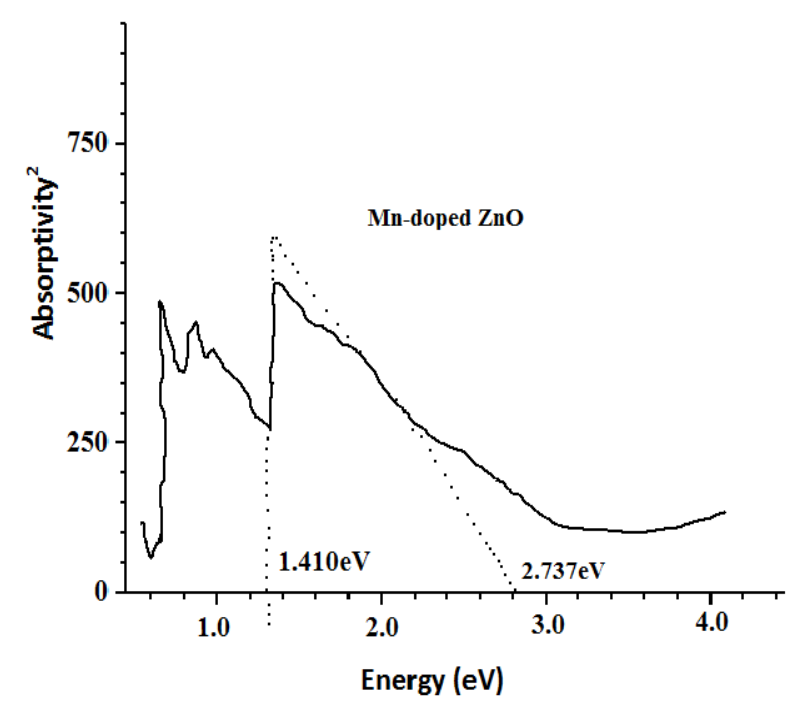

(b)

Figure 4: Band gap energy data of un-doped $\mathrm{ZnO}$ (a) and Mn-doped $\mathrm{ZnO}$ nanoparticles (b)

In the case of $\mathrm{Mn}$-doped $\mathrm{ZnO}$ nanoparticles, the lowest IC $\mathrm{C}_{50}$ of $39 \pm 0.22 \mu \mathrm{g} / \mathrm{mL}$ was obtained at a concentration of $1000 \mu \mathrm{g} / \mathrm{mL}$ and the highest $\mathrm{IC}_{50}$ of $78 \pm 0.25 \mu \mathrm{g} / \mathrm{mL}$ was seen at $60 \mu \mathrm{g} / \mathrm{mL}$. The DPPH free radical scavenging activity increased with increasing concentration of the Mn-doped $\mathrm{ZnO}$ nanoparticles. At a level $1000 \mu \mathrm{g} / \mathrm{mL}$, Mndoped $\mathrm{ZnO}$ nanoparticles showed significant DPPH radical scavenging activity comparable to that of BHT with $\mathrm{IC}_{50}$ value of $48 \pm 0.29 \mu \mathrm{g} / \mathrm{mL}$. This indicates that the Mn-doped $\mathrm{ZnO}$ nanoparticles possess high antioxidant activities in terms of scavenging of DPPH free radicals.

High level of total phenolic content $(20.1 \pm 0.21$ $\mathrm{mg} / 100 \mathrm{~g} \mathrm{GAE}$ ) was obtained at a concentration of $1000 \mu \mathrm{g} / \mathrm{mL}$, while the lowest total phenolic content (0.95 $\pm 0.08 \mathrm{mg} / 100 \mathrm{~g}$ GAE) was observed at $60 \mu \mathrm{g} / \mathrm{mL}$ of un-doped $\mathrm{ZnO}$ nanoparticles. A similar pattern was seen at different concentrations of $\mathrm{Mn}$-doped $\mathrm{ZnO}$ nanoparticles, although the corresponding values doped $\mathrm{ZnO}$ nanoparticles should be less than 3 $\mathrm{eV}$. This is in agreement with the band gap energy value for $\mathrm{Mn}$-doped $\mathrm{ZnO}$ nanoparticles in this study, which was less than $3 \mathrm{eV}$ (Figure $4 \mathrm{~b}$ ).

\section{Antioxidant activity}

The results of DPPH radical scavenging assay for different concentrations of un-doped $\mathrm{ZnO}$ nanoparticles are shown in Table 1 in the form of $I C_{50}$ values. The lowest $I C_{50}$ value $(41 \pm 0.32$ $\mu \mathrm{g} / \mathrm{mL}$ ) was seen at a concentration of 1000 $\mu \mathrm{g} / \mathrm{mL}$, while the highest $\mathrm{IC}_{50}$ value $(85 \pm 0.23$ $\mu \mathrm{g} / \mathrm{mL}$ ) was obtained at a concentration of 60 $\mu \mathrm{g} / \mathrm{mL}$ for un-doped $\mathrm{ZnO}$ nanoparticles.

were higher when compared with un-doped $\mathrm{ZnO}$ nanoparticles (the percentage of total phenolic contents varied from $1.09 \pm 0.18$ to $23.1 \pm 0.31$ $\mathrm{mg} / 100 \mathrm{~g} \mathrm{GAE}$ at various concentrations i.e. 60 $125,250,500$ and $1000 \mu \mathrm{g} / \mathrm{mL}$ of Mn-doped $\mathrm{ZnO}$ nanoparticles). These results are shown in Table 1 , and they indicate that the TPCs of the undoped $\mathrm{ZnO}$ and $\mathrm{Mn}$-doped $\mathrm{ZnO}$ nanoparticles were concentration-dependent. The results of antioxidant activities of different concentrations of un-doped and $\mathrm{Mn}$-doped $\mathrm{ZnO}$ nanoparticles, with respect to inhibition of linoleic acid oxidation, are shown in Table 1. The percentage inhibition values of linoleic acid peroxidation were $18 \pm$ $0.23,31 \pm 0.19,43 \pm 0.15,50 \pm 0.17$ and $63 \pm$ 0.21 at $60,125,250,500$ and $1000 \mu \mathrm{g} / \mathrm{mL}$, respectively, for un-doped $\mathrm{ZnO}$ nanoparticles. Maximum percentage inhibition was $63 \pm 0.21 \%$ (at $1000 \mu \mathrm{g} / \mathrm{mL}$ ), while the minimum percentage inhibition (18 $\pm 0.23 \%$ ) was recorded at 60 $\mu \mathrm{g} / \mathrm{mL}$. For $\mathrm{Mn}$-doped $\mathrm{ZnO}$ nanoparticles, percentage inhibitions varied from $21 \pm 0.13$ to 
$65 \pm 0.11 \%$. Higher inhibition of linoleic acid oxidation was observed in Mn-doped $\mathrm{ZnO}$ nanoparticles than in un-doped $\mathrm{ZnO}$ nanoparticles. Linoleic oxidation was significantly inhibited by the un-doped $\mathrm{ZnO}$ and Mn-doped $\mathrm{ZnO}$ nanoparticles at all the levels tested, and the percentage inhibition was comparable to that of $\mathrm{BHT}$ which produced $61 \pm 0.19 \%$ inhibition.

In the FRAP assay, maximum antioxidant activity of $8.99 \pm 0.21 \mu \mathrm{M} / \mathrm{mL}$ TE was produced by 1000 $\mu \mathrm{g} / \mathrm{mL}$ while minimum antioxidant activity of 0.59 $\pm 0.01 \mu \mathrm{M} / \mathrm{mL}$ TE was observed with $60 \mu \mathrm{g} / \mathrm{mL}$ of un-doped $\mathrm{ZnO}$ nanoparticles. The antioxidant activity of $\mathrm{Mn}$-doped $\mathrm{ZnO}$ nanoparticles varied from $0.79 \pm 0.11$ to $10.9 \pm 0.11 \mu \mathrm{M} / \mathrm{mL}$ TE. Higher FRAP was exhibited by Mn-doped $\mathrm{ZnO}$ nanoparticles than un-doped $\mathrm{ZnO}$ nanoparticles. These results are also shown in Table 1.

\section{Antibacterial activity}

The results of antibacterial activity of the undoped $\mathrm{ZnO}$ and $\mathrm{Mn}$-doped $\mathrm{ZnO}$ nanoparticles are shown in Tables 2 and 3. The un-doped $\mathrm{ZnO}$ nanoparticles, at $5 \mathrm{mg}$ and at $3 \mathrm{mg}$ exhibited significant antibacterial activities against $B$. subtilis, with ZOIs of $17 \pm 0.11 \mathrm{~mm}$ and $15 \pm 0.07$ $\mathrm{mm}$, respectively. Against Klebsiella, the ZOls were $15 \pm 0.05$ and $13 \pm 0.04 \mathrm{~mm}$, respectively. At 5 and $3 \mathrm{mg}$, the un-doped $\mathrm{ZnO}$ nanoparticles demonstrated effective bactericidal activity with minimum inhibitory concentrations (MICs) of 0.09 and $0.13 \mathrm{mg} / \mathrm{mL}$, respectively for Klebsiella.

MICs of 0.07 and $0.04 \mathrm{mg} / \mathrm{mL}$ were obtained at 3 $\mathrm{mg}$ and at $5 \mathrm{mg}$, respectively for $B$. subtilis. Compared to the standard drug cephradine (1 $\mathrm{mg}$ ), it was evident that $5 \mathrm{mg}$ was much more effective for Klebsiella and $B$. subtilis.

ZOls of cephradine for Klebsiella and $B$. subtilis were $12 \pm 0.05 \mathrm{~mm}$ and $14 \pm 0.09 \mathrm{~mm}$, respectively. Higher bactericidal potential was exhibited by $\mathrm{Mn}$-doped $\mathrm{ZnO}$ nanoparticles relative to the standard drug and un-doped $\mathrm{ZnO}$ nanoparticles (Table 3). Mn-doped $\mathrm{ZnO}$ nanoparticles (at $5 \mathrm{mg}$ ) produced stronger inhibition of the growth of $E$. coli, $S$. aureus, Klebsiella and $B$. subtilis, with ZOls of $13 \pm 0.09$, $14 \pm 0.01,18 \pm 0.07$ and $20 \pm 0.10$, respectively. The MICs of Mn-doped $\mathrm{ZnO}$ nanoparticles (at 5 $\mathrm{mg}$ ) ranged from 0.03 to $0.09 \mathrm{mg} / \mathrm{mL}$. Thus, the Mn-doped ZnO nanoparticles showed very effective broad spectrum antibacterial activities.

Table 1: Antioxidant activity of synthesized un-doped $\mathrm{ZnO}$ and $\mathrm{Mn}$-doped $\mathrm{ZnO}$ nanoparticles

\begin{tabular}{|c|c|c|c|c|c|}
\hline S/no. & $\begin{array}{c}\text { Concentration } \\
(\mu \mathrm{g} / \mathrm{mL})\end{array}$ & $\begin{array}{l}\mathrm{DPPH}\left(\mathrm{IC}_{50}\right. \\
\mu \mathrm{g} / \mathrm{mL})\end{array}$ & $\begin{array}{c}\text { FRAP }(\mu M / m L \\
\text { as TE) }\end{array}$ & $\begin{array}{c}\text { TPC } \\
\text { (mg/100g as } \\
\text { GAE) }\end{array}$ & $\begin{array}{l}\text { Inhibition of } \\
\text { linoleic acid } \\
\text { oxidation (\%) }\end{array}$ \\
\hline \multicolumn{6}{|c|}{ M1 NAPs } \\
\hline 1 & 60 & $85 \pm 0.23$ & $0.59 \pm 0.01$ & $0.95 \pm 0.08$ & $18 \pm 0.23$ \\
\hline 2 & 125 & $71 \pm 0.30$ & $1.88 \pm 0.12$ & $2.01 \pm 0.11$ & $31 \pm 0.19$ \\
\hline 3 & 250 & $68 \pm 0.29$ & $3.01 \pm 0.09$ & $5.01 \pm 0.15$ & $43 \pm 0.15$ \\
\hline 4 & 500 & $56 \pm 0.33$ & $4.68 \pm 0.19$ & $11.2 \pm 0.25$ & $50 \pm 0.17$ \\
\hline 5 & 1000 & $41 \pm 0.32$ & $8.99 \pm 0.21$ & $20.1 \pm 0.21$ & $63 \pm 0.21$ \\
\hline 6 & $\mathrm{BHT}$ & $48 \pm 0.29$ & - & - & $61 \pm 0.19$ \\
\hline \multicolumn{6}{|c|}{ M2 NAPs } \\
\hline 1 & 60 & $78 \pm 0.25$ & $0.79 \pm 0.11$ & $1.09 \pm 0.18$ & $21 \pm 0.13$ \\
\hline 2 & 125 & $65 \pm 0.36$ & $2.08 \pm 0.02$ & $4.99 \pm 0.01$ & $35 \pm 0.29$ \\
\hline 3 & 250 & $58 \pm 0.25$ & $4.01 \pm 0.19$ & $8.01 \pm 0.25$ & $48 \pm 0.05$ \\
\hline 4 & 500 & $49 \pm 0.20$ & $7.40 \pm 0.09$ & $15.3 \pm 0.05$ & $56 \pm 0.27$ \\
\hline 5 & 1000 & $39 \pm 0.22$ & $10.9 \pm 0.11$ & $23.1 \pm 0.31$ & $65 \pm 0.11$ \\
\hline 6 & $\mathrm{BHT}$ & $48 \pm 0.29$ & - & - & $61 \pm 0.19$ \\
\hline
\end{tabular}

Table 2: ZOIs in antibacterial test of un-doped $\mathrm{ZnO}$ nanoparticles against different bacterial strains

\begin{tabular}{|c|c|c|c|c|c|c|}
\hline \multirow[b]{2}{*}{ Bacterial strain } & \multicolumn{3}{|c|}{ Inhibition zone diameter (mm) } & \multicolumn{3}{|c|}{ MIC (mm) } \\
\hline & $\begin{array}{c}\text { Standard } \\
(1 \mathrm{mg})\end{array}$ & $\begin{array}{c}\text { M1 NAPs } \\
(5 \mathrm{mg})\end{array}$ & $\begin{array}{c}\text { M1 NAPs } \\
(3 \mathrm{mg})\end{array}$ & $\begin{array}{c}\text { Standard } \\
(1 \mathrm{mg})\end{array}$ & $\begin{array}{c}M 1 \\
\text { NAPs } \\
(5 \mathrm{mg})\end{array}$ & $\begin{array}{c}\text { M1 NAPs } \\
\text { (3 mg) }\end{array}$ \\
\hline E. coli & $11 \pm 0.09$ & $8 \pm 0.08$ & $7 \pm 0.04$ & 0.30 & 0.80 & 0.95 \\
\hline S. aureus & $13 \pm 0.05$ & $11 \pm 0.11$ & $8 \pm 0.09$ & 0.10 & 0.95 & 1.01 \\
\hline Klebsiella & $12 \pm 0.05$ & $15 \pm 0.05$ & $13 \pm 0.04$ & 0.14 & 0.09 & 0.13 \\
\hline B. subtilis & $14 \pm 0.09$ & $17 \pm 0.11$ & $15 \pm 0.07$ & 0.08 & 0.04 & 0.07 \\
\hline
\end{tabular}

Values are mean \pm SD $(n=3)$. M1 NAPs = un-doped ZnO nanoparticles, MIC= Minimum inhibition concentration, Standard $=$ cephradine 
Table 3: ZOls in antibacterial test of Mn-doped ZnO nanoparticles against different bacterial strains

\begin{tabular}{|c|c|c|c|c|c|c|}
\hline \multirow[b]{2}{*}{ Bacterial strain } & \multicolumn{3}{|c|}{ Inhibition zone diameter (mm) } & \multicolumn{3}{|c|}{ MIC (mm) } \\
\hline & $\begin{array}{c}\text { Standard } \\
(1 \mathrm{mg})\end{array}$ & $\begin{array}{c}\text { M2 NAPs } \\
\text { (5mg) }\end{array}$ & $\begin{array}{c}\text { M2 NAPs } \\
\text { (3mg) }\end{array}$ & $\begin{array}{c}\text { Standard } \\
(1 \mathrm{mg})\end{array}$ & $\begin{array}{c}\text { M2 NAPs } \\
\text { (5mg) }\end{array}$ & $\begin{array}{c}\text { M2 NAPs } \\
\text { (3mg) }\end{array}$ \\
\hline E. coli & $11 \pm 0.09$ & $13 \pm 0.09$ & $9 \pm 0.05$ & 0.30 & 0.09 & 0.90 \\
\hline S. aureus & $13 \pm 0.07$ & $14 \pm 0.01$ & $11 \pm 0.08$ & 0.10 & 0.08 & 0.85 \\
\hline Klebsiella & $12 \pm 0.05$ & $18 \pm 0.07$ & $14 \pm 0.05$ & 0.14 & 0.07 & 0.11 \\
\hline B. subtilis & $14 \pm 0.09$ & $20 \pm 0.10$ & $17 \pm 0.06$ & 0.08 & 0.03 & 0.05 \\
\hline
\end{tabular}

Values are mean $\pm S D(n=)$. M2 NAPs = Mn-doped ZnO nanoparticles, MIC= Minimum inhibition concentration, Standard $=$ ephradine

\section{DISCUSSION}

XRD spectra demonstrated that the presence of intense and sharp peaks in the XRD spectra of the synthesized un-doped $\mathrm{ZnO}$ and Mn-doped $\mathrm{ZnO}$ nanoparticles. This confirmed their crystalline nature. The average calculated grain size of the un-doped $\mathrm{ZnO}$ and $\mathrm{Mn}$-doped $\mathrm{ZnO}$ nanoparticles were 16.72 and $17.5 \mathrm{~nm}$, respectively. These results demonstrate that the grain size of the doped $\mathrm{ZnO}$ nanoparticles is larger than that of the un-doped $\mathrm{ZnO}$ nanoparticles. This is due to the fact that $\mathrm{Mn}$ doping results in an increase in grain size. Thus the grain size of $\mathrm{ZnO}$ nanoparticles was increased by $\mathrm{Mn}$ doping. The particle size was decreased due to increase in the percentage of $\mathrm{Mn}$ or doping with Mn. These findings are in agreement with previous reports $[18,19]$.

SEM results affirmed the nanoscale range of particle size for the un-doped $\mathrm{ZnO}$ and the $\mathrm{Mn}$ doped $\mathrm{ZnO}$ nanoparticles and also confirmed their wurtzite crystalline structures [15]. Results from EDX were consistent with those from SEM and XRD. The major constituents of the nanoparticles were $\mathrm{Zn}, \mathrm{O}$ and $\mathrm{Mn}$. The strong, intense, narrow width and sharp peaks in the EDX spectrum indicated that the un-doped $\mathrm{ZnO}$ and $\mathrm{Mn}$-doped $\mathrm{ZnO}$ were crystalline in nature [15]. There were agreement and close relationship in the results of the various characterization techniques, which is an indication of successful synthesis of the nanoparticles. Band gap data was lower in $\mathrm{Mn}$ doped $\mathrm{ZnO}$ nanoparticles than in the un-doped $\mathrm{ZnO}$. This is likely due to the fact that Mn doping decreased band gap energy value since the band gap energy obtained for the doped product was less than $3.0 \mathrm{eV}$ value for semiconductors $[16,17]$.

Different concentrations of the synthesized undoped $\mathrm{ZnO}$ and Mn-doped $\mathrm{ZnO}$ were investigated for antioxidant potential through total antioxidant assays (DPPH radical scavenging, FRAP, inhibition of linoleic acid peroxidation and TPC). Mn-doped $\mathrm{ZnO}$ nanoparticles produced better antioxidant results than the un-doped $\mathrm{ZnO}$ nanoparticles and BHT, while un-doped $\mathrm{ZnO}$ nanoparticles showed antioxidant activity comparable to $\mathrm{BHT}$. This was due to the fact that doping with Mn enhanced the antioxidant activity of un-doped $\mathrm{ZnO}$ nanoparticles [5]. The results also revealed that the antioxidant activities of the nanoparticles were concentration-dependent [12]. These results are consistent with previously reported data $[8,20,21]$.

The un-doped $\mathrm{ZnO}$ nanoparticles at $5 \mathrm{mg}$ produced higher antibacterial effects than the standard drug cephradine in the inhibition of growth of Klebsiella, and Bacillus subtilis, while the $\mathrm{Mn}$-doped $\mathrm{ZnO}$ nanoparticles exhibited greater bactericidal effect in contrast to standard drug and un-doped $\mathrm{ZnO}$ nanoparticles in inhibiting the growth of these organisms. This significant bactericidal activity was due to the release of $\mathrm{Mn}^{+2}$ ions and $\mathrm{Zn}^{+2}$ from Mn-doped $\mathrm{ZnO}$ nanoparticles, and the permeation of the bacterial cell membrane by these ions. The permeation of $\mathrm{Mn}^{+2}$ and $\mathrm{Zn}^{+2}$ ions was possible due to the attraction of their positive charges to the negatively-charged cell wall. The binding of these ions destroyed the bacterial cell membrane. In addition, $\mathrm{Mn}^{+2}$ ions and $\mathrm{Zn}^{+2}$ ions are involved in cross-linkage of nucleic acid strands by binding with DNA molecules of bacteria. This produces a disorder in the DNA structure, leading to protein denaturation and complete destruction of the bacterial cell $[5,20,21]$.

\section{CONCLUSION}

The results of this study indicate that although the synthesized un-doped $\mathrm{ZnO}$ nanoparticles possess potent and desirable biological properties such as antibacterial and antioxidant activities, Mn-doped $\mathrm{ZnO}$ nanoparticles showed better results than un-doped $\mathrm{ZnO}$ nanoparticles. This is due to the large surface and smaller particle size of Mn-doped nanoparticles. Thus, the synthesized nanoparticles hold enormous potential for use in the cosmetic, nutraceutical and pharmaceutical industries. 


\section{DECLARATIONS}

\section{Acknowledgement}

This work was supported by the Department of Chemistry, School of Science, University of Management and Technology, Lahore, Pakistan.

\section{Conflict of Interest}

No conflict of interest associated with this work.

\section{Contribution of Authors}

The authors declare that this work was done by the authors named in this article and all liabilities pertaining to claims relating to the content of this article will be borne by them.

\section{Open Access}

This is an Open Access article that uses a funding model which does not charge readers or their institutions for access and distributed under the terms of the Creative Commons Attribution License (http://creativecommons.org/licenses/by/ 4.0) and the Budapest Open Access Initiative (http://www.budapestopenaccessinitiative.org/rea d), which permit unrestricted use, distribution, and reproduction in any medium, provided the original work is properly credited.

\section{REFERENCES}

1. Anukaliani A, Manjula G, Nair M, Nirmala M, Rekha K. Structural, optical, photocatalytic and antibacterial activity of $\mathrm{ZnO}$ and $\mathrm{Co}$ doped $\mathrm{ZnO}$ nanoparticles. Mat Lette 2011; 65: 1797-1800.

2. Gubin SP. Magnetic nanoparticles. Wiley-VCH 2009; ISBN 3-527-40790-1.

3. Yadav A, Parsad $V$, Kathe AA, Raj $S$, Yadav D, Sundaramoorthy $C$, Vigneshwaran $N$. Functional finishing in cotton fabrics using zinc oxide nanoparticles. Bull Mater Sci 2006; 29: 641-645.

4. Djuisic $A B$, Leung $Y H$, Choy $W C H$, Cheah $K W$, Chan WK. Visible photoluminescence in $\mathrm{ZnO}$ tetrapod and multipod structure. Appl Phys Lett 2004; 84(14): 2635 2637.

5. Reddy KM, Feris $K$, Bell J, Wingett DG, Hamley $C$, Punnoose A. Selective toxicity of zinc oxide nanoparticles to prokaryotic and eukaryotic system. Appl Phys Lett 2007; 90: 2139021-2139023.

6. Yan XX, Xu GY. Effect of sintering atmosphere on the electrical and optical properties of $(\mathrm{ZnO}) 1-x(\mathrm{MnO}) x$ NTCR Ceramics. Physica B 2009; 404(16): 2377-2381.
7. Abdollahi $Y$, Abdullah H, Zainal Z, Yusof NA. Synthesis and characterization of $\mathrm{Mn}$-doped $\mathrm{ZnO}$ nanoparticles. Int J Bas appl Sci 2011; 11(04): 62-69.

8. Wang $Y$, Zhao X, Duan L, Wand F, Niu H, Guo W, Ali A. Structure luminescence and photocatalytic activity of Mn-doped ZnO nanoparticles prepared by auto combustion method. Mat Sci Semi Process 2015; 29: 372-379.

9. Chawla S, Jayanthi SK. Fabrication of ZnO:Mn nanoparticles with organic shell in a highly alkaline aqueous environment. Appl Surf Sci 2011; 257: 29352939.

10. Khan SA, Rasool N, Riaz M, Nadeem R, Rashid U, Rizwan K, Zubair M, Bukhari IH, Gulzar T. Evaluation of Antioxidant and Cytotoxicity Studies of Clerodendrum inerme. Asian J Chem 2013; 13: 7457-7462

11. Khan $S A$, Shahid $S$, Jameel $M$, Ahmad A. In vitro antibacterial, antifungal and GC-MS analysis of seeds of Mustard Brown. Int J Pharm Chem 2016; 6(4): 107-115.

12. Ijaz F, Shahid S, Khan SA, Ahmad W, Zaman S. Green synthesis of copper oxide nanoparticles using Abutilon indicum leaf extract: Antimicrobial, antioxidant and photocatalytic dye degradation activities. Trop J Pharm Res 2017; 16(4): 743-753.

13. Khan SA, Shahid S, Khan ZA, Iqbal A. Assessment of stabilization of canola oil, free radical scavenging and cytotoxic potential of Peucedanum graveolens (roots). Int J Sci and Res Pub 2016; 6(3): 529-535.

14. Khan SA, Shahid S, Ahmad W, Ullah S. Pharmacological Importance of Clerodendrum Genus: A Current Review. Int J Pharm Sci Res 2017; 2(2): 22-30.

15. Tam KH, Djurisic AB, Chan CMN, Xi YY, Tse CW, Leung $Y H$, Chan WK, Leung FCC, Au DWT. Antibacterial activity of $\mathrm{ZnO}$ nanoroads prepared by a hydrothermal method. Thi Sol Film 2008; 516(18): 6167-6174.

16. Hoffman $M$, Martin $S$, Choi W, Behnemann $D$, Environmental applications of semiconductor photo catalysis. Chem Rev 1995; 95: 69-96.

17. Halperin B, Lax M. Impurity-band tails in the high-density limit I. Minimum counting methods. Phys Rev 1966; 148(2): 722-740.

18. Yang M, Guo ZX, Qui K, Long J, Yin G, Guan D, Liu S, Zhou S. Synthesis and characterization of Mn-doped ZnO column arrays. Appl Surf Sci 2010; 256(13): 4201 4205.

19. Straumal B, Baretzky B, Mazilkin A, Protasava S. Increase of $M n$ solubility with decreasing grain size in ZnO. J Eur Cera Soci 2009; 29: 1963-1970.

20. Ahmad W, Khan SA, Munawar KS, Khalid A, Kanwal S. Synthesis, characterization and pharmacological evaluation of mixed ligand-metal complexes containing omeprazole and 8-hydroxyquinoline. Trop J Pharm Res 2017; 16(5): 1137-1146.

21. Khan SA, Shahid S, Sajid MR, Noreen F, Kanwal S. Biogenic Synthesis of CuO Nanoparticles and their Biomedical Applications: A Current Review. Int J Adv Res 2017; 5(6): 925-946. 